\title{
PREDICTIVE MODELING OF Mimosa tenuiflora (WILLD) POIRET: HOW CAN CLIMATE CHANGE AFFECT ITS POTENTIAL DISTRIBUTION RANGE?
}

\author{
Kyvia Pontes Teixeira das Chagas $^{1 *}$, Fernanda Moura Fonseca Lucas², Fábio de Almeida Vieira ${ }^{3}$ \\ ${ }^{1 *}$ Universidade Federal do Paraná, Programa de Pós-Graduação em Engenharia Florestal, Curitiba, PR, Brasil - kyviapontes@gmail.com \\ ${ }^{2}$ Universidade Federal do Paraná, Programa de Pós-Graduação em Engenharia Florestal, Curitiba, PR, Brasil - fernanda- \\ fonseca@hotmail.com \\ ${ }^{3}$ Universidade Federal do Rio Grande do Norte, Escola Agrícola de Jundiaí, Macaíba, RN, Brasil - vieirafa@gmail.com
}

Received for publication: 24/11/2018 - Accepted for publication: 20/05/2019

\begin{abstract}
Resumo
Modelagem preditiva de Mimosa tenuiflora (Willd) Poiret: como as mudanças climáticas poderão afetar a ocorrência da espécie? Estudos que caracterizam os efeitos dos fatores climáticos na distribuição geográfica de indivíduos arbóreos são de fundamental importância, principalmente para espécies de potencial madeireiro amplamente exploradas, como é o caso da Mimosa tenuiflora (Willd) Poiret (jurema-preta). Nesse sentido, o objetivo deste trabalho foi predizer as áreas climaticamente adequadas para a ocorrência de Mimosa tenuiflora no presente (1960-1990) e no futuro (2070). O algoritmo Maxent foi utilizado para relacionar os registros de ocorrência da espécie com as variáveis climáticas. Para o ano de 2070, foram testados dois cenários para os seguintes modelos de circulação geral da atmosfera: HadGEM2-ES, GISS-E2-R e MIROC-ESM. A modelagem para o presente apresentou um índice de AUC (área sob a curva) de $0,94( \pm 0,02)$, indicando bom ajuste do modelo utilizado. Já para o cenário futuro, o valor da AUC variou entre 0,88 a 0,89 e 0,87 a 0,88 para os cenários otimista e pessimista, respectivamente. A maior porcentagem de contribuição foi para a variável precipitação anual. As áreas de adequabilidade ocuparam, em maior intensidade e quase que por totalidade, os Estados do Ceará e do Rio Grande do Norte. Quando comparado ao presente, o território geográfico com alta adequabilidade para o futuro apresentou redução de $28,7 \%$ a $53,7 \%$ no cenário otimista, e $30,9 \%$ a $59,4 \%$ para o cenário pessimista. As informações obtidas podem ser utilizadas como subsídio para o estabelecimento de plantios comerciais, definição de estratégias de manejo e conservação, bem como a criação de um banco de conservação in situ para a espécie Mimosa tenuiflora.

Palavras-chave: jurema-preta, predição de habitat, Caatinga, Fabaceae.
\end{abstract}

\begin{abstract}
Studies that characterize the effects of climatic factors on the geographic distribution of arboreal individuals are of fundamental importance, especially for widely exploited species of wood potential, such as Mimosa tenuiflora (Willd) Poiret (jurema-preta). In this sense, the objective of this work was to predict the climatically adequate areas for the occurrence of Mimosa tenuiflora, present (1960-1990) and future (2070). We used the Maxent algorithm to relate the occurrence records of the species to the climatic variables. For the year 2070, we test two scenarios and three general atmospheric circulation models, HadGEM2-ES, GISS-E2-R and MIROC-ESM. Modeling for the present presented an AUC index (area under the curve) of $0.94( \pm 0.02)$, indicating a good fit of the model used. For the future scenario, the AUC value ranged from 0.88 to 0.89 and 0.87 to 0.88 for the optimistic and pessimistic scenarios, respectively. The highest percentage of contribution was to the annual precipitation variable. The areas of adequacy occupied the states of Ceara and Rio Grande do Norte in higher intensity and almost all of them. When compared to the present, the geographic territory with high suitability for the future presented a reduction from $28.7 \%$ to $53.7 \%$ in the optimistic scenario and $30.9 \%$ to $59.4 \%$ in the pessimistic scenario. The information obtained can be used as a subsidy for the establishment of commercial plantations, the definition of management and conservation strategies, and the creation of an in situ conservation bank for Mimosa tenuiflora species.

Keywords: jurema-preta, habitat prediction, Caatinga, Fabaceae.
\end{abstract}

\section{INTRODUCTION}

The Brazilian Northeast is mostly composed of xerophytic vegetation called Caatinga, a little-studied biome very threatened and occupying approximately $11 \%$ of the national territory. The low level of precipitation is a limiting factor for the vegetative occurrence in this biome, together with the intense process of anthropization and illegal deforestation for the purpose of obtaining firewood (OLIVEIRA; BERNARD, 2017). 
Logging is one of the main factors responsible for the alteration in forest composition, which can lead to the mischaracterization of habitats or the extinction of species. In the State of Paraíba, for example, approximately $71 \%$ of timber demand comes from native forest species. Therefore, it is estimated that $55.8 \%$ comes from illegal deforestation (NDAGIJIMANA et al., 2015). According to Pareyn (2010), the timber market in the Northeast is very informal, with a high supply of illegal firewood at low cost. The low price of this illegal firewood allows for indiscriminate exploitation, which can cause serious ecological problems, in addition to the extinction of rare species.

In recent decades, global climate change has altered the distribution of species, becoming the main factor responsible for the extinction of many plant species (PEARSON et al., 2014). Among the four global climate domains, the tropical one has the highest rate of forest destruction and degradation (HANSEN et al., 2013). In this way, ecological conservation studies with tropical vegetation are growing increasingly. Among forms of life, trees are more susceptible to the effects of climate change, presenting changes in phenology and its distribution, which can affect the entire forest ecosystem (BUTT et al., 2015). Therefore, it is important to know the ecological factors that influence the distribution of individuals and the areas of geographical distribution. Ecological niche models (ENM) are used as tools to predict the geographic distribution of species, based on geographic information of species occurrences and data on environmental variables (PHILLIPS et al., 2006). These models can help to understand the geographical limits and the mechanisms that determine the distribution of species of interest (GUISAN; ZIMMERMANN, 2000). Also, they can act as indicators of priority in the development of management plans and the definition of priority areas for conservation.

Among the various algorithms used for modeling is the Maxent (Maximum Entropy Model), widely used for its ease of handling and good performance (ELITH et al., 2006; PHILLIPS et al., 2006). This algorithm estimates the probability of occurrence of a given species based on the maximum entropy probability distribution, the distribution closest to the uniform distribution. It has the advantage of requiring only the points of occurrence (presence) and climate variables to perform the modeling (PHILLIPS et al., 2006).

In this sense, the objective of this work was to analyze the geographic distribution and to predict the climatically adequate areas for the occurrence of Mimosa tenuiflora. It is believed that the results presented in the present work can serve as a basis for the establishment of management and conservation strategies for the species. Have the following hypotheses been tested: I) over the years, will climate change negatively affect the occurrence of Mimosa tenuiflora? II) could areas with low suitability in the present become areas with high suitability in future prediction? III) will annual rainfall be the variable with the most significant influence in determining the potential suitability of areas?

\section{MATERIAL AND METHODS}

\section{Target species}

Mimosa tenuiflora is popularly known as "jurema-preta", and representative of the Fabaceae family. Its main products are stakes, firewood and coal, in addition to the medicinal properties and tanning substances present in its shell (MAGALHÃES et al., 2018). It typically occurs in semi-arid natural areas from the State of Piauí to Bahia, besides being an indicator of early stages of ecological succession in anthropized environments (CARVALHO, 2000).

\section{Acquisition and data processing}

Mimosa tenuiflora occurrence records were obtained from the collections catalogued on the free SpeciesLink scientific platform (http://splink.cria.org.br), selecting only data that contained geographic coordinates. Besides the selected records, known geographical coordinates were used, those coming from expeditions in the State of Rio Grande do Norte. For the current (present) period prediction, 19 layers of climate data were used, with different temperature, precipitation and seasonal conditions, obtained through the WorldClim version 1.4 site, with a spatial resolution of 30 arc-second $(\sim 1 \mathrm{~km})$.

With the help of ENMTools v. 1.4.3 (http://purl.oclc.org/enmtools), the geographical data were analysed, and subsequently the overlapping points and lost coordinates, such as location in the ocean, houses, squares, among others, were excluded. For the 19 climate variables calculated, Pearson's correlation coefficients were used to reduce the model overfitting. The variables that were highly correlated, i.e., had a value of $r \geq 0.85$ were excluded, either this positive or negative value (WEI et al., 2017). From this procedure, the multicollinearity between the variables is reduced, and the model provides accurate information without overfitting the contribution of climate variables (COSTA et al., 2018; WEI et al., 2017). 


\section{Modeling of ecological niche}

The analyses were carried out for the current period, defined on the basis of the average of the years 1960-1990, and for the future period, average of the years 2061 to 2080. Regarding the future (2070), the predictions for the optimistic scenario RCP2.6 and the pessimistic scenario RCP8.5 were carried out, both in three models of the general circulation of the atmosphere (AGCM), HadGEM2-ES, GISS-E2-R and MIROC-ESM (GOBERVILLE et al., 2015; WATANABE et al., 2011). In the optimistic scenario RCP2.6, CO2 concentrations not exceeding about $450 \mathrm{ppm}$ (close to current estimates of greenhouse gas concentrations) and $\mathrm{CH} 4 \mathrm{reaching}$ approximately $1800 \mathrm{ppb}$. The pessimistic RCP8.5 scenario reflects high levels of greenhouse gas emissions, resulting in radioactive forces of $8.5 \mathrm{~W} / \mathrm{m}^{2}$ by 2100 (representative concentration route - Intergovernmental Panel on Climate Change - IPCC) (VAN VUUREN et al., 2011).

Maxent software version 3.3.3k was used to model potential geographical distribution areas (PHILLIPS et al., 2006). Maxent, a model of maximum entropy, predicts the distribution of a given species through a combination of occurrence data with climatic variables. Also, to verify the contribution of each variable, the Jackknife statistical test was used.

In order to obtain a more comprehensive distribution to allow the model time for convergence, five thousand interactions were used. In addition, the data were submitted to 10 cross-validate repetitions. The evaluation of the models was performed by calculating the parameter area under the curve (AUC), which ranges from 0,5 to 1, being 1 the best value for model adjustment (PHILLIPS et al., 2006).

For the construction of the distribution map and potential suitability of the species, the information was submitted to the Quantum GIS program (QGIS) v. 3.0.0 (https://www.qgis.org/pt_BR/site/). Suitability has its indication performed using a color gradient scale, where each pixel has the value ranging from 0 to 1 . The values that indicate higher environmental suitability have a redder color, while the bluer shades indicate a lower probability of occurrence. In addition with the help of the QGIS, the territorial extension $\left(\mathrm{km}^{2}\right)$ was quantified with the suitability classified as high.

\section{RESULTS}

After the survey of available collections, 146 records of occurrence of the species were obtained. It was verified the occurrence in eight of the nine states of the Northeast region: Alagoas, Bahia, Ceará, Paraíba, Pernambuco, Piauí, Rio Grande do Norte and Sergipe (Figure 1).

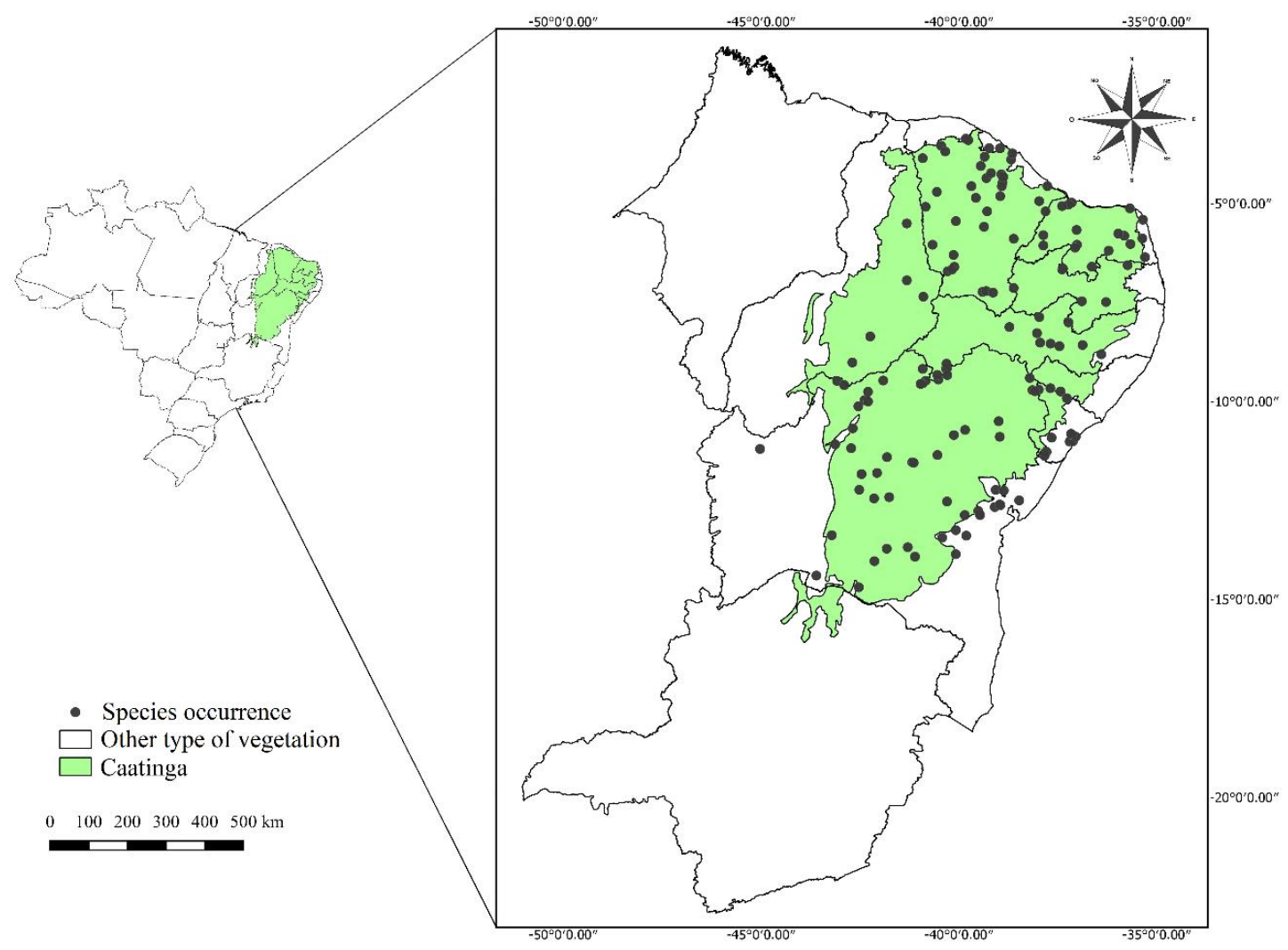

FLORESTA, Curitiba, PR, v. 50, n. 2, p. 1315 - 1324, abr/jun 2020. 
Figura 1. Distribuição geográfica de Mimosa tenuiflora nos Estados do Brasil.

Figure 1. Geographic distribution of Mimosa tenuiflora in the Brazilian states.

The State of Bahia presented the highest number of occurrences, representing $37.67 \%$ of the total, followed by Ceará, with $26.03 \%$, and Rio Grande do Norte, with $13.01 \%$ (Table 1). The sum of records in these three states represents $76.71 \%$ of the total number of occurrences. The States with lower percentage values were Alagoas, Paraíba and Piauí, with only $0.68 \%, 2.74 \%$ and $3.42 \%$, respectively.

Tabela 1. Registros de ocorrência de Mimosa tenuiflora por Estados brasileiros.

Table 1. Records of occurrence of Mimosa tenuiflora by the Brazilian states.

\begin{tabular}{ccc}
\hline States & $\mathrm{N}^{\circ}$ of occurrences & Occurrences $(\%)$ \\
\hline Alagoas & 1 & 0.68 \\
Bahia & 55 & 37.67 \\
Ceará & 38 & 26.04 \\
Paraíba & 4 & 2.74 \\
Pernambuco & 13 & 8.90 \\
Piauí & 5 & 3.42 \\
Rio Grande do Norte & 19 & 13.02 \\
Sergipe & 11 & 7.53 \\
\hline Total & 146 & 100 \\
\hline
\end{tabular}

For the ecological niche modeling, among the 19 variables initially analyzed, 11 were selected for the final model after the analysis of Pearson's correlation coefficients (Table 2). The modeling for the present period presented an AUC index of 0.94 and a standard deviation of \pm 0.02 . The Jackknife test demonstrated that the variable with the most significant gain, when used alone, is the annual rainfall, with the higher value of useful information aggregated. The highest contribution percentages were for the variables annual precipitation, thermal amplitude and average daytime temperature variation, with values of $58.3,11.4$ and $11.3 \%$, respectively. Regarding the percentage of permutation, the most significant variables were annual precipitation, minimum temperature of the coldest month and current thermal amplitude (Table 2).

Tabela 2. Valores de contribuição e importância de permutação das variáveis ambientais para a modelagem de nicho ecológico da Mimosa tenuiflora para o período de 1960-1990.

Table 2. Contribution values and importance of permutation of environmental variables for Mimosa tenuiflora ecological niche modeling for the current period 1960-1990.

\begin{tabular}{llcc}
\hline Variables & \multicolumn{1}{c}{ Description } & Contribution (\%) & $\begin{array}{c}\text { Importance of } \\
\text { permutation (\%) }\end{array}$ \\
\hline bio 12 & Annual precipitation & 58.3 & 73.8 \\
bio 07 & Current temperature range & 11.4 & 6.9 \\
bio 02 & Average daytime temperature change & 11.3 & 2.8 \\
bio 18 & Hottest quarter precipitation & 7.3 & 0.6 \\
bio 14 & Precipitation of the driest month & 2.6 & 1.0 \\
bio 06 & Minimum temperature of the coldest month & 2.3 & 7.6 \\
bio 13 & Precipitation of the rainiest month & 1.9 & 3.4 \\
bio 05 & Mximum temperature of the hottest month & 1.6 & 0.5 \\
bio 03 & Isotermality & 1.5 & 0.5 \\
bio 08 & Average temperature of the wettest quarter & 1.1 & 1.7 \\
bio 19 & Precipitation of the coldest quarter & 0.7 & 1.2 \\
\hline
\end{tabular}

For the future, in the RCP2.6 scenario, the highest percentage of contribution and the highest importance of permutation was observed for the annual precipitation variable, for the three models of the general circulation 
of the atmosphere analyzed (AGCM) (Table 3). The value of AUC had little variation between the models, with the lowest value of 0.88 for MIROC-ESM and GISS-ES-R and the highest of 0.89 for HadGEM2-ES. Concerning the RCP8.5 scenario, it was observed the same behavior of the present and the optimistic scenario, where the variable with higher values for percentage of contribution and importance of permutation was the annual precipitation, in all the analyzed models (Table 3). The lowest value of AUC was 0.87 for MIROC-ESM and higher than 0.88 for HadGEM2-ES and GISS-ES-R.

Tabela 3. Valores de contribuição, importância de permutação e AUC das variáveis ambientais para a modelagem de nicho ecológico da Mimosa tenuiflora para o ano de 2070, nos cenários RCP2.6 (otimista) e RCP8.5 (pessimista), considerando os três modelos de circulação geral da atmosfera.

Table 3. Contribution values, the importance of permutation and AUC of the environmental variables for Mimosa tenuiflora ecological niche modeling for the year 2070, in the scenarios RCP2.6 (optimistic) and RCP8.5 (pessimistic), considering the three general circulation models of the atmosphere.

\begin{tabular}{|c|c|c|c|c|c|c|c|}
\hline \multicolumn{2}{|r|}{ Scenario/ Period } & \multicolumn{6}{|c|}{ RCP2.6 optimist (2070) } \\
\hline \multirow[b]{2}{*}{ Variables } & \multirow[b]{2}{*}{ Description } & \multicolumn{2}{|c|}{ HadGEM2-ES } & \multicolumn{2}{|c|}{ GISS-ES-R } & \multicolumn{2}{|c|}{ MIROC-ESM } \\
\hline & & $\% \mathrm{C}$ & $\%$ IP & $\% \mathrm{C}$ & $\%$ IP & $\% \mathrm{C}$ & $\%$ IP \\
\hline bio 02 & Average daytime temperature change & 5.7 & 4.0 & 14.8 & 5.3 & 4.9 & 3.1 \\
\hline bio 03 & Isotermality & 4.2 & 1.4 & 1.1 & 1.4 & 0.7 & 1.3 \\
\hline bio 05 & Maximum temperature of the hottest month & 2.3 & 2.6 & 1.4 & 1.1 & 1.9 & 1.6 \\
\hline bio 06 & Minimum temperature of the coldest month & 0.8 & 0.8 & 2.8 & 8.4 & 1.2 & 1.4 \\
\hline bio 07 & Current temperature range & 27.1 & 18.1 & 22.4 & 10.6 & 30.4 & 12.4 \\
\hline bio 08 & Average temperature of the wettest quarter & 2.9 & 1.2 & 3.1 & 2.1 & 3.5 & 2.0 \\
\hline bio 12 & Annual precipitation & 49.1 & 40.9 & 45.9 & 54.4 & 42.0 & 55.9 \\
\hline bio 13 & Precipitation of the rainest month & 1.2 & 3.9 & 2.4 & 9.0 & 6.7 & 9.6 \\
\hline bio 14 & Precipitation of the driest month & 0.9 & 2.2 & 0.6 & 1.2 & 1.0 & 4.0 \\
\hline bio 18 & Precipitação do trimestre mais quente & 3.6 & 11.7 & 4.7 & 1.8 & 6.3 & 6.2 \\
\hline bio 19 & Precipitation of the coldest quarter & 2.4 & 13.2 & 0.7 & 4.6 & 1.4 & 2.5 \\
\hline & AUC & & 0.02 & $0.88 \pm$ & 0.02 & 0.88 & 0.02 \\
\hline \multirow{2}{*}{\multicolumn{2}{|c|}{ Scenario/ Period }} & \multicolumn{6}{|c|}{ RCP8.5 pessimistic (2070) } \\
\hline & & \multicolumn{2}{|c|}{ HadGEM2-ES } & \multicolumn{2}{|c|}{ GISS-ES-R } & \multicolumn{2}{|c|}{ MIROC-ESM } \\
\hline Variables & Description & $\% \mathrm{C}$ & $\%$ IP & $\% \mathrm{C}$ & $\%$ IP & $\% \mathrm{C}$ & $\%$ IP \\
\hline bio 02 & Average daytime temperature change & 6.0 & 4.2 & 29.1 & 4.3 & 15.9 & 1.6 \\
\hline bio 03 & Isotermality & 2.9 & 1.4 & 1.0 & 0.3 & 1.9 & 1.4 \\
\hline bio 05 & Maximum temperature of the hottest month & 7.1 & 6.2 & 1.7 & 0.8 & 1.2 & 0.1 \\
\hline bio 06 & Minimum temperature of the coldest month & 0.4 & 1.6 & 2.0 & 2.5 & 3.6 & 2.7 \\
\hline bio 07 & Current temperature range & 22.4 & 19.1 & 9.6 & 6.5 & 12.4 & 19.6 \\
\hline bio 08 & Average temperature of the wettest quarter & 4.6 & 3.8 & 3.6 & 1.1 & 2.5 & 1.9 \\
\hline bio 12 & Annual precipitation & 47.5 & 43 & 33.6 & 60.5 & 28.8 & 28.5 \\
\hline bio 13 & Precipitation of the rainest month & 2.7 & 4.5 & 3.6 & 18.3 & 6.9 & 6.8 \\
\hline bio 14 & Precipitation of the driest month & 1.0 & 2.0 & 1.4 & 1.8 & 2.2 & 4.3 \\
\hline bio 18 & Hottest quarter precipitation & 3.3 & 9.4 & 12.4 & 1.6 & 15.5 & 14.8 \\
\hline bio 19 & Precipitation of the coldest quarter & 2.0 & 4.8 & 2.2 & 2.3 & 9.2 & 18.3 \\
\hline & AUC & \multicolumn{2}{|c|}{$0.88 \pm 0.01$} & \multicolumn{2}{|c|}{$0.88 \pm 0.02$} & \multicolumn{2}{|c|}{$0.87 \pm 0.02$} \\
\hline
\end{tabular}

$\% \mathrm{C}=$ Contribution; \% IP = Importance of permutation. 
For the environmental conditions of the current period, Mimosa tenuiflora presented an area of suitability widely distributed throughout the Northeast of Brazil, occupying the states of Ceará and Rio Grande do Norte to a large extent, and almost entirely (Figure 2). The states of Alagoas, Bahia, Paraíba, Pernambuco, Piauí and Sergipe present more suitable areas in lesser territorial extension.

It was verified a reduction in the areas of suitability from the current period to the future (2070), both in the optimistic and pessimistic scenarios and in all the models tested (Figure 2). However, it was not verified the appearance of new classified areas with high suitability, indicating that, in general, for the future period, there will be a reduction of existing areas. Only for the states of Alagoas and Pernambuco, in the coastal region, and for Bahia, in the Northwest region, the appearance of a small area with high suitability was verified in the HadGEM2ES and GISS-E2-R models (Figure 2B and2C).

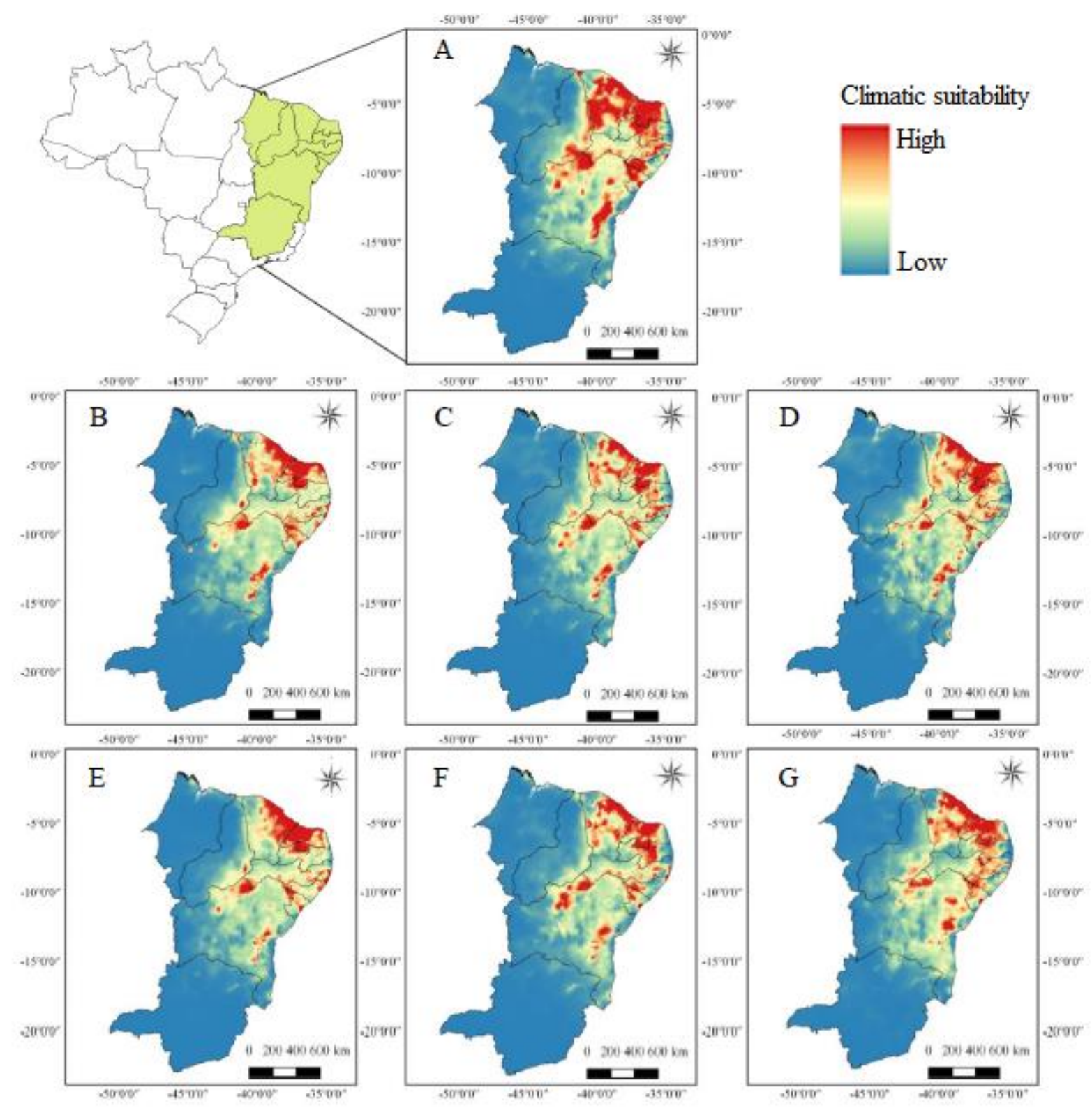

Figura 2. Distribuição e potencial de adequabilidade de Mimosa tenuiflora no Brasil para o período atual e futuro (2070). Presente (A); cenário otimista RCP2.6 para 2070: HadGEM2-ES (B), GISS-E2-R (C), MIROC-ESM (D); cenário pessimista RCP8.5 para 2070: HadGEM2-ES (E), GISS-E2-R (F) e MIROC-ESM (G).

Figure 2. Distribution and the potential suitability of Mimosa tenuiflora in Brazil for the current and future period (2070). Present (A); optimistic scenario RCP2.6 to 2070: HadGEM2-ES (B), GISS-E2-R (C), MIROC-ESM (D); pessimistic scenario RCP8.5 to 2070: HadGEM2-ES (E), GISS-E2-R (F) and MIROC-ESM (G). 
In relation to the geographic territory, the current period presented $139,577 \mathrm{~km}^{2}$ of the classified area with high suitability. When analyzing these areas in the optimistic scenario, it was quantified a reduction in the suitability territory of $53.7 \%$ for the HadGEM2-ES model, $42.9 \%$ for GISS-E2-R and $28.7 \%$ for MIROC-ESM. Regarding the pessimistic scenario, compared to the current period, there was a more significantreduction in the territory of suitability, with the HadGEM2-ES model losing about 59.4\%, GISS-E2-R 44.8\% and MIROC-ESM $30.9 \%$.

\section{DISCUSSION}

Most occurrences of Mimosa tenuiflora are located in the Caatinga vegetation, and some other points occur in distinct vegetational types, such as Cerrado, Restinga and transition zones. The only State in the Northeast that did not present the occurrence of Mimosa tenuiflora was the State of Maranhão, for which no researches of floristic survey with this species have been found in the literature This fact can be explained because of the other predominant vegetational types in the State, being these: Mangues, Cerrado, Mata dos Cocais and Amazônia (BARRETO et al., 2013; SILVA et al., 2008)

Lemos and Zappi (2012), when studying the geographical distribution of woody plants, observed that the species Mimosa tenuiflora showed a disjunct distribution. In other words, it can be found in geographically distant regions in South America, such as Venezuela, Colombia, Panama, Honduras, Mexico and Brazil. When considering the geographical distribution only in Brazil, a pattern of occurrence similar to the present study was obtained, in which the State of Bahia had the highest proportion of occurrences of individuals, followed by the State of Ceará (LEMOS; ZAPPI, 2012).

Based on the results obtained, it can be stated that the Northeast region provides favorable environmental characteristics for the establishment and development of individuals of Mimosa tenuiflora. This species is rustic, tolerating extreme situations, such as long periods of drought, and has a deep root system for appropriate development in degraded soils (AZEVEDO et al., 2012).

Regarding the modeling for the present, the AUC value obtained (0.94) was considered high, which indicates a suitable adjustment of the model used and high predictive power (COSTA et al., 2018). The areas of suitability almost entirely occupied Ceará and Rio Grande do Norte, which suggests that these states are highly recommended for the creation of conservation banks in situ, enabling the conservation of genetic materials of this species. When the species has a more restricted distribution, AUC values tend to be higher (YANG et al., 2013), which was observed for the present study, because the species Mimosa tenuiflora presents a restricted distribution in the Northeast region of Brazil, predominantly in areas of Caatinga, but occurring in transition zones.

The variable with the most significant influence was the annual precipitation, which was expected, since, in the Caatinga, place of natural incidence of the species, this climatic variable is a limiting factor for the vegetative occurrence. The high importance of the annual precipitation variable is probably related to the process of fruit dispersion, anemochory type, characteristic of Mimosa tenuiflora, performed during the driest periods (PIRANI et al., 2009).

The use of modeling tools is growing due to the possibility of obtaining information that may help in conservation strategies, since it is possible to predict the behavior of the species in the face of the effects of climate change, in addition to the determination of areas susceptible to the occurrence of invasive species (GIANNINI, 2012; RODRIGUES et al., 2015). In addition, it contributes information on the definition of favourable sites for commercial plantations and the establishment of conservation strategies for threatened species (CONTRERASMEDINA et al., 2010).

In general, the models of the future varied little concerning the AUC value, between 0.87 and 0.88 , showing good prediction of the model (RODRIGUES et al., 2015). However, they varied according to the areas per state and according to the models of the general circulation of the atmosphere, whereby, for HadGEM2-ES, the southwestern region of Ceará, Paraíba and Alagoas presented the most evident reduction. For the GISS-E2-R model, the highlight is for the State of Piauí, which, in this prediction, did not show appropriate areas for the occurrence Mimosa tenuiflora. The MIROC-ESM model indicated a relatively more subtle reduction in suitability when compared to the others, exhibiting areas of suitability in smaller size, but basically in the same places as the prediction for the present.

Among the models tested, the HadGEM2-E2 showed the prediction with the most drastic change scenario, in which the area had the most considerable reduction of territory, decreasing to less than half of the present area. Thus, the long-term effects of climate change will have a negative effect. New studies should be carried out to allow the comparison between the areas, through the use of other variables, such as soil characteristics, relief and economic factors, which can help in decision-making for commercial implementation or conservationist purposes (NABOUT et al., 2016). The prediction tool can have a positive influence on the maintenance of population

FLORESTA, Curitiba, PR, v. 50, n. 2, p. 1315 - 1324, abr/jun 2020.

Chagas, K. P. T. et.al.

ISSN eletrônico 1982-4688

DOI: $10.5380 /$ rf.v50 i2. 62980 
ecosystems, since by analyzing climate variations, areas can be defined that are conducive to the implementation of new conservation strategies, such as in situ conservation banks (COSTA et al., 2018). Furthermore, the map of suitability can be used as a tool for the definition of suitable sites for commercial deployment, determining an environment where the species will have the appropriate conditions for its proper development.

The information obtained can be used for ecological studies, which subsidize the understanding of evolutionary history, when associated with phylogeography studies, besides the establishment of appropriate areas for the planting and development of the species. It is becoming more and more important to create a program to improve the species, allowing better use and utilization of its products, in addition to enabling the maintenance of Mimosa tenuiflora in native vegetation.

\section{CONCLUSION}

- The models used performed well, with high predictive power. The states of Ceará and Rio Grande do Norte were the ones that presented the most extensive territorial range of areas with high suitability for the current period.

- When compared to the future, the areas of suitability showed a reduction, indicating that climate change may negatively affect the occurrence of Mimosa tenuiflora.

- For future prediction, the emergence of large areas with high suitability was not visualized

- The climate variable with the most significant influence to determine the occurrence of the species was the annual precipitation

\section{ACKNOWLEDGEMENTS}

The present work was carried out with the support of the Coordenação de Aperfeiçoamento de Pessoal de Nível Superior - Brazil (CAPES) - Financing Code 001.

\section{REFERENCES}

AZEVEDO, S.M.A.; BAKKE, I.A.; BAKKE, O.A.; FREIRE, A.L. O. Crescimento de plântulas de jurema preta (Mimosa tenuiflora (Wild) Poiret) em solos de áreas degradadas da caatinga. Engenharia Ambiental, Espírito Santo do Pinhal. v. 9, n. 3, p. 150-160, 2012.

BARRETO, L.; SCHOORL, J. M.; KOK, K.; VELDKAMP, T.; HASS, A. Modelling potential landscape sediment delivery due to projected soybean expansion: A scenario study of the Balsas sub-basin, Cerrado, Maranhão state, Brazil. Journal of Environmental Management, v.115, n. 30, p. 270-277, 2013. doi: 10.1016/j.jenvman.2012.11.017.

BUTT, N.; SEABROOK, L.; MARON, M.; LAW, B. S.; DAWSON, T. P.; SYKTUS, J.; MCALPINE, C. A. Cascading effects of climate extremes on vertebrate fauna through changes to low-latitude tree flowering and fruiting phenology. Global Change Biology, v. 21, p. 3267-3277, 2015. doi: 10.1111/gcb.12869

CARVAlhO, A. J. E.; GARIGLIO, M. A.; CAMPELlO, F. B.; BARCELlOS, N. D. E. Potencial econômico de recursos florestais em áreas de assentamento do Rio Grande do Norte. Ministério do Meio Ambiente. Natal, RN, 2000 .

CONTRERAS-MEDINA, R.; LUNA-VEGA, I.; RIOS-MUÑOZ, C. A. Distribución de Taxus globosa (Taxaceae) en México: Modelos ecológicos de nicho, efectos del cambio del uso de suelo y conservación. Revista Chilena de História Natural. v. 83, p. 421-433, 2010. doi: 10.4067/S0716-078X2010000300009.

COSTA, T. R.; MOURA, C. C.; MACHADO, E. L. M.; BUENO, M. L. Modelagem preditiva da espécie Lychnophora pohii SCH. BIP, no Estado de Minas Gerais. Nativa, v.6, n.1, p. 100- 106, 2018. doi: 10.31413/nativa.v6i1.4696

ELITH, J.; GRAHAM, C.H.; ANDERSON, R.P.; DUDÍK, M.; FERRIER, S.; GUISAN, A.; HIJMANS, R.J.; HUETTMANN, F.; LEATHWICK, J.R.; LEHMANN, A.; LI, J.; LOHMANN, L.G.; LOISELLE, B.A.; MANION, G.; MORITZ, C.; NAKAMURA, M.; NAKAZAWA, Y.; OVERTON, J.M.; PETERSON, A.T.; PHILLIPS, S.J.; RICHARDSON, K.; SCACHETTIPEREIRA, R.; SCHAPIRE, R.E.; SOBERÓN, J.; WILLIAMS, S.; WISZ, M.S.; ZIMMERMANN, N.E. Novel methods improve prediction of species distributions from occurrence data. Ecography, v. 29, p. 129-151, 2006. doi: 10.1111/j.2006.0906-7590.04596.x 
GIANNINI, T. C.; SIQUEIRA, M. F.; ACOSTA, A. L.; BARRETO, F. C. C.; SARAIVA, A. M.; SANTOS, A. I. Desafios atuais da modelagem preditiva de distribuição de espécies. Rodriguésia, v.63, p.733-749, 2012. doi: $10.1590 / \mathrm{S} 2175-78602012000300017$.

GOBERVILLE, E.; BEAUGRAND, G.; HAUTEKÈETE, N. C.; PIQUOT, Y.; LUCZAK, C. Uncertainties in the projection of species distributions related to general circulation models. Ecology and evolution, v. 5, p. 11001116, 2015. doi: 10.1002/ece3.1411.

GUISAN, A.; ZIMMERMANN, N. E. Predictive habitat distribution models in ecology. Ecological Modelling, v. 135, p. 147-186, 2000.

HANSEN, M. C.; POTAPOV, P. V.; MOORE, R.; HANCHER, M.; TURUBANOVA, S.; TYUKAVINA, A.; THAU, D.; STEHMAN, S.V.; GOESTZ, S. J.; LOVELAND, T. R.; KOMMAREDDY, A.; EGOROV, A.; CHINI, L. JUSTICE, C. O.; TOWNSHEND, J. R. G. High-resolution global maps of 21st-century forest cover change. Science, v. 342, p. 850-853, 2013. doi: 10.1126/science.1244693

LEMOS, J. R.; ZAPPI, D. C. Distribuição geográfica mundial de plantas lenhosas da Estação Ecológica de Aiuaba, Ceará, Brasil. Revista Brasileira de Biociências. Porto Alegre, v. 10, n. 4, p. 446-456, 2012.

MAGALHÃES, F.E.A; BATISTA, F.L.A.; SERPA, O.F.; MOURA, L.F.W.G.; LIMA, M.C.L.; SILVA, A.R.A.; NOGUEIRA, A.B.; BARBOSA, T.M.; HOLANDA, B.A.; DAMASCENO, M.B.W.V.; MELO JÚNIOR, J.M.A.; BARROSO, L.K.V.; CAMPOS, A.R. Orofacial antinociceptive effect of Mimosa tenuiflora (Willd.) Poiret. Biomedicine \& Pharmacotherapy, v. 97, p. 1575-1585, 2018. doi: 10.1016/j.biopha.2017.11.001

NABOUT, J. C.; MAGALHÃES, M. R.; GOMES, M. A. A.; CUNHA, H. F. The impact of global climate change on the geographic distribution and sustainable harvest of Hancornia speciosa Gomes (Apocynaceae) in Brazil. Environmental Management, v. 57, p. 814-821, 2016. doi: 10.1007/s00267-016-0659-5

NDAGIJIMANA, C.; PAREYN, F. G. C.; RIEGELHAULPT, E. Uso do solo e desmatamento da Caatinga: um estudo de caso na Paraíba e no Ceará - Brasil. Estatística Florestal da Caatinga, Recife, v. 2, n. 2, p. 18-29. 2015.

OLIVEIRA, A. P. C.; BERNARD, E. The financial needs vs. the realities of in situ conservation: an analysis of federal funding for protected areas in Brazil's Caatinga. Biotropica, Washington, v. 49, p. 745-752, 2017. doi: $10.1111 /$ btp. 12456.

PAREYN, F. G. C. Os recursos florestais nativos e a sua gestão no Estado de Pernambuco - O papel do manejo florestal sustentável. In: Gariglio, M. A.; Sampaio, E. V. S. B.; Cestaro, L. A.; Kageyama, P. Y. (Eds.). Uso sustentável e conservação dos recursos florestais da Caatinga. Brasília: SFB, 2010. 368 p. p. 99-115.

PEARSON, R. G.; STANTON, J. C.; SHOEMAKER, K. T.; AIELlO-LAMMENS, M. E.; ERSTS, P. J.; HORNING, N.; FORDHAM, D. A.; RAXWORTHY, C. J.; RYU, H. Y.; MCNEES, J.; AKÇAKAYA, H. R. Life history and spatial traits predict extinction risk due to climate change. Nature Climate Change, v.4, p.217-221, 2014.

PHILlIPS, S. J.; ANDERSON, R. P.; SCHAPIRE, R. E. Maximum entropy modeling of species geographic distributions. Ecological Modelling, v. 190, p. 231-259, 2006. doi: 10.1016/j.ecolmodel.2005.03.026.

PIRANI, J. R.; SANCHEZ, M.; PEDRONI, F. Fenologia de uma comunidade arbórea em cerrado sentido restrito, Barra das Garças, MT, Brasil. Acta Botanica Brasilica, v.23, p. 1096-1109, 2009. doi: 10.1590/S010233062009000400019.

RODRIGUES, P. M. S.; SILVA, J. O.; EISENLOHR, P.V.; Schaefer, C. E. G. R. Climate change effects on the geographic distribution of specialist tree species of the Brazilian tropical dry forests. Brazilian Journal of Biology, v. 75, n. 3, p. 679-684, 2015. doi: 10.1590/1519-6984.20913.

SILVA, H. G.; FIGUEIREDO, N.; ANDRADE, G. V. Estrutura vegetacional de um Cerradão e a heterogeneidade regional do Cerrado no Maranhão, Brasil. Revista Árvore, v.32, n. 5, p. 921-930, 2008. doi: 10.1590/S010067622008000500017.

WATANABE, S.; HAJIMA, T.; SUDO, K.; NAGASHIMA, T.; TAKEMURA, T.; OKAJIMA, H.; NOZAWA, T.; KAWASE, H.; ABE, M. YOKOHATA, T.; ISE, T.; SATO, H.; KATO, E.; TAKATA, K.; EMORI, S.; KAWAMIYA, M. MIROC-ESM 2010: Model description and basic results of CMIP5-20c3m experiments. Geoscientific Model Development, v. 4, n. 1, p. 845-872, 2011. doi: 10.5194/gmd-4-845-2011.

FLORESTA, Curitiba, PR, v. 50, n. 2, p. 1315 - 1324, abr/jun 2020.

Chagas, K. P. T. et.al.

ISSN eletrônico 1982-4688 
WEI, J.; ZHANG, H.; ZHAO, W.; ZHAO, Q. Niche shifts and the potential distribution of Phenacoccus solenopsis (Hemiptera: Pseudococcidae) under climate change. Plos one. n. 12, v. 7, p. 1- 17, 2017. doi: 10.1371/journal.pone.0180913.

YANG, X. Q.; KUSHWAHA, S. P. S.; SARAN, S.; XU, J. C.; ROY, P. S. Maxent modeling for predicting the potential distribution of medicinal plant, Justicia adhotoda L. in Lesser Himalayan foothills. Ecological Engineering, v. 51, p. 83- 87, 2013. doi: 10.1016/j.ecoleng.2012.12.004. 